\title{
Külföldi idénymunkások a magyar agrárgazdaságban
}

\section{Migrants in Hungarian agriculture}

\author{
HAMAR ANNA
}

HAMAR Anna: tudományos munkatárs, MTA Közgazdaság- és Regionális Tudományi Kutatóközpont, Regionális Kutatások Intézete, Budapest; hamara@rkk.hu

KULCSSZAVAK: agrárfoglalkoztatás, migráció, napszámos, szezonális munka

ABSZTRAKT: A tanulmány egy folyamatban lévő OTKA-kutatás keretében elemzi az agrárfoglalkoztatás szerkezetében végbement változások kapcsolatát a nemzetközi migrációs folyamattal, a külföldi idénymunkások szerepvállalását a magyar mezőgazdaságban. A tanulmány bemutatja a migráns mezőgazdasági idénymunkások számában és összetételében végbement változás folyamatát, munkavállalásuk térbeli jellegzetességét és a kapitalizmuskori munkaszervezési formákkal együtt újraéledő termelői hálózatokat, valamint a munkavállaló és foglalkoztató között kialakult kapcsolat sajátos formáit.

Az agrárium strukturális átalakulása, az üzemek számának és munkaerőigényének ugrásszerü növekedése az idénymunka piacának kialakulásához, új munkavállalói csoportok megjelenéséhez és a hagyományos munkaszervezési formák újraéledéséhez, felerősödéséhez vezetett. Az agrárfoglalkoztatás szerkezetének átalakulása egy időben zajlott a nemzetközi migráció kiterjedésével, melybe a szomszédos országok állampolgárai is bekapcsolódtak. Az olcsó bérezésű, a foglalkoztató szükségleteihez rugalmasan alkalmazkodó munkavállalók között a külföldi - döntőrészt romániai - idénymunkások megjelenése a kapcsolati hálók, a munkaszervezési formák térbeli, országhatárt átlépő kiterjesztéséhez, gazdagodásához, a rendelkezésre álló munkások számának emelkedéséhez vezetett. A külföldi idénymunkások számának csökkenésével, etnikai és társadalmi összetételének változásával a migránsokat mozgató termelői hálózatok részben meggyengültek, részben differenciálódtak, de vannak olyan térségek is, ahol teljesen eltűntek. Bármennyire is látványos a külföldi munkások számának csökkenése a munkaerőhiányos térségekben, amíg a két ország között létező bér- és jövedelmi különbségek nem csökkennek, a romániai napszámosok a magyar gazdaságok munkaerő-utánpótlását biztosítják. A migráns mezőgazdasági idénymunkások heterogén csoportjai között az elmúlt másfél évtizedben végbement a foglalkoztató számára értékes munkavállalói kör kiválasztódása, melynek tagjai eltérő formában kötődnek a munkát biztosító gazdaságokhoz, termelőkhöz.

Anna HAMAR: research fellow, Institute for Regional Studies, Centre for Economic and Regional Studies, Hungarian Academy of Sciences, Budapest; hamara@rkk.hu

KEYWORDS: agricultural labour, seasonal labour, migration, farmworker

ABSTRACT: As part of an ongoing survey, this study analyses the correlation between the changes in agricultural employment and the process of international migration as well as the role of foreign seasonal labourers in Hungarian agriculture.

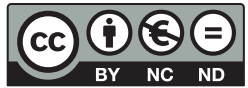


The first part of the paper contains a perusal of statistical data and investigates the quality of changes and the territorial placement of foreign seasonal workers. The second part describes the established organisation of work and networks, as well as the characteristic groups of seasonal farm workers, based on interviews conducted with farmers and seasonal labourers.

The structural changes within agriculture after the change of the political system and the ensuing boom in labour demand on farms led to the establishment of a market for seasonal labour, the emergence of new employee groups, and the revival and strengthening of traditional labour structures. The changes in agricultural employment occurred simultaneously with the increase in international migration which the citizens of neighbouring countries joined as well.

Among the low-wage employees, flexibly accommodating the needs of their employers, the appearance of foreign - especially Romanian - seasonal labourers led to an extension of labourorganising relational networks, increased border crossing and a surge in the number of available seasonal workers. Although the numbers of foreign seasonal labourers in regions with a shortage of labour decreased significantly in recent years, Romanian day-labourers will continue to contribute to the local agricultural workforce as long as the wage differences between the two countries will not decrease.

Meanwhile, the composition of the ethnic and societal background of seasonal workers has changed, the farmers' networks for mobilising migrants have weakened and became partially differentiated, so that there are now regions in which they have completely disappeared.

Hungarian farmers could not keep all their seasonal labourers after Romania's accession to the EU in 2007, since jobseekers preferred countries with a higher wage level. Nevertheless a valuable labour pool made up of heterogeneous groups of migrant seasonal labourers formed over the past fifteen years. Its members are bound in different ways to the farms and the farmers who offer them work.

\section{Bevezetés}

A tanulmány az agrárium szerkezetében zajló folyamatokkal, szerkezeti változásokkal és a vidék átalakulásával foglalkozó OTKA-kutatás ${ }^{1}$ keretében készült. A tanulmány elkészítéséhez felhasználtuk az elérhető statisztikai adatokat, a szakirodalmat és a termelőkkel, az idénymunkásokkal készített strukturált és félig strukturált interjúkat. ${ }^{2}$

A magyar agrárfoglalkoztatás szerkezetében az elmúlt évtizedben a legnagyobb változást az időszaki alkalmazottak ${ }^{3}$ számának ugrásszerü emelkedése hozta. 86 ezer fö időszaki alkalmazott dolgozott 2013-ban a gazdaságokban, 53 százalékkal több, mint 2010-ben (KSH 2014). Az időszaki munkaerő felhasználásának aránya az élőmunka-igényes zöldség- és gyümölcstermesztésben a legmagasabb, a gyümölcsösökben 70,2 százalék, a kertészeti ágazatokban 60,6 százalék volt 2010-ben (Koós, Kovács 2012). Az agrárfoglalkoztatás szerkezetének változása, az időszaki alkalmazottak számának emelkedése a gazdaság munkaerö-szükségletének átalakulását jelzi (Bíró, Székely 2012; FruitVeb 2012). A munkaszervezésben felértékelődtek a rövid ideig foglalkoztatott, alacsony bérezésü, egy-egy feladatra alkalmazott munkavállalók, akik foglalkoztatásuk alatt legalább egy fóállású dolgozó munkaidejét teljesítik, annak hosszú idejü foglalkoztatásával járó bérköltségei nélkül.

A gazdaságok munkaerőigénye, különösen a szőlő-, gyümölcs- és zöldségkertészeti ágazatokban újra felélesztette, felerősítette a kapitalizmuskori ma- 
gyar mezőgazdaságra jellemző, kapcsolathálóba rendeződő, kooperációt biztosító intézményrendszereket, többek közt a kliens-patrónus hálózatokat, a napszámos piacot, egy-egy konkrét feladatra szerveződő bandákat, valamint a summáscsapat szerveződési formáit (Katona 1961; Sárközi 1972).

A néhány hónapig tartó mezőgazdasági munkacsúcsok alatt a gazdaságok megugró munkaerő-kereslete nagyszámú idénymunkás foglalkoztatását igényli. A munkavégzés hosszú évekig jelentős részben a feketegazdaságban zajlott, melyet az állam az alkalmi munka szabályozásával (Frey 2010; Semjén, Tóth, Fazekas 2008), valamint az agrártámogatások megvonásának lehetőségével igyekezett legális keretek közé terelni. A foglalkoztatóra nehezedő közterhek mérséklése, az egyszerűsített adminisztráció, a munkaszerződések nem kötelezővé tétele olyan alkalmi foglalkoztatási rendszer kialakulását eredményezte, ${ }^{4}$ mely az illegális munkavégzést, ha meg nem is szüntette, de hozzájárult visszaszorításához. Az időszaki munkavállalói csoport számbeli nagyságáról és gazdasági súlyáról árulkodik, hogy létszámuk szeptemberben, az idénymunkák torlódásakor a legmagasabb, ebben a hónapban átlagosan 75-80 ezer mezőgazdasági munkavállaló jelenik meg a (legális) alkalmi munkaerőpiacon (Ehretné, Hamza, Rácz 2015).

Külföldi tanulmányok sora mutatja be a foglalkoztatás szerkezetének változását, a munkához rugalmasan alkalmazkodó, mobil és alacsony bérezésü munkavállalóra épülő új munkaerő-piaci szegmens kialakulását, amely elválaszthatatlanul összekapcsolódik a nemzetközi migráció kiszélesedésével és a migráns munkavállalói csoportok megjelenésével. A rugalmas munkaerőt az amerikai gazdaság számára a mexikói migránsok (Nelson, Nelson, Trautman 2014), míg Kanada mezőgazdasági üzemei részére a közép-amerikai (Preibisch 2012), Dél-Európa mezőgazdaságának az észak-afrikai, az albán, valamint a kelet-európai migráns munkavállalók biztosítják. A külföldi munkások jelenléte olyannyira meghatározza a déli országok mezőgazdaságát, hogy azt a kutatók dél-európai modellként írják le (Kasimis 2009). Az albániai migránsok munkavállalása hozzájárult a görög gazdaságok munkaszervezetének átalakulásához, a családtagok mezőgazdaságon kívüli foglakoztatásához, a gazdaságokon belül a tőke és a munka sokkal rugalmasabb kombinációjának kialakulásához (Jentsch 2007; Kasimis 2009). A spanyol epertermelés fellendülését, piaci részesedésének növekedését az EU belső piacainak megnyitása tette lehetővé, de az uniós tagság egyúttal munkaerőhiánnyal is fenyegetett, mert a hazai napszámosok, élve a munkavállalás lehetőségével, a magasabb bért fizető tagországok munkaerőpiacait választják. A rendszert a migránsok tartják életben, munkaerő-piaci mozgásukat, a munkaerőpiacra való ki- és belépésüket származási országuk Európai Unióhoz csatlakozása és a tagsággal járó előnyök elérhetősége befolyásolja. Lengyelország 2004. évi csatlakozása után a Spanyolországban dolgozó lengyel vendégmunkások elhagyták a szamócaföldeket. Már nem kényszerültek rá a spanyol ügynökségek által szervezett foglalkoztatás keretében olyan szerződés aláírására, mely csak az ügynökség által kijelölt gazdaságban adott szá- 
mukra legális munkavégzést. Ezzel a megkötéssel megakadályozták a szabad mozgásukat a munkaerőpiacon és nem utolsósorban növelték annak a valószínűségét, hogy a szerződés lejártával visszatérnek hazájukba, nem növelik az illegálisan Spanyolországban tartózkodó külföldiek számát. A munkások, megszabadulva a szerződéssel kikényszerített „gazdasághoz kötéstől”, egy jobban fizető ágazatban vállaltak munkát Spanyolországban vagy más országokban próbáltak szerencsét. Számuk jelentősen lecsökkent a spanyol idénymunkapiacon, és hasonlót vártak a románoktól is, így felértékelődnek a marokkóiak és a különböző afrikai és unión kívüli országok (ukrán, moldáv) potenciális munkavállalói (Mannon, Petrzelka, Glass, Radel 2012; Soltész 2010). A külföldi munkavállalók munkaerejére építenek a norvég gazdaságok is, melyek a hazainál olcsóbb bérü munkaerőt, elsősorban lengyeleket foglalkoztatnak (Andrzejewska, Rye 2012).

A kilencvenes években Magyarországon kialakuló alkalmi munkaerőpiacot a magyar és a külföldi idénymunkások jelenléte határozza meg, még ha a két csoport térben és időben eltérő mértékben és intenzitással vesz is részt a mezőgazdasági munkákban. A szomszédos országokból (Románia, Ukrajna) érkező idénymunkások olcsó munkaerőt jelentettek a gazdaságok számára. Míg az ukrajnai munkavállalók száma alacsony volt és maradt, ez már nem mondható el a romániai migránsokról, akiknek száma emelkedett, majd folyamatosan apadt és etnikai összetételük is változott. Az unióban országonként eltérő mértékben emelkedik az Európai Unión belüli és kívüli államokból érkező mezőgazdasági munkások száma (kivéve Franciaországot és Hollandiát) (Loughrey, Donnellan, Hanrahan, Henessy 2013). Magyarországon napjainkra általában elvesztették jelentőségüket a külföldi munkavállalók az idénymunka piacán, de a munkaerőhiánnyal küszködő térségekben továbbra is meghatározó szereplők, akik különböző hálózatokon keresztül mozognak, vagy élve a törvényes lehetőséggel, letelepedtek, de fö megélhetésüket továbbra is a napszámba járás biztosítja.

\section{Vendégmunkások, idénymunkások a statisztika tükrében}

A kilencvenes évek elején új munkavállalói kör alakult ki a külföldi idénymunkások megjelenésével és térnyerésével. Az idénymunkások migrációja belesimult a nyolcvanas évek utolsó harmadában felerősödő, a kilencvenes évek első felében kiteljesedő, az utóbbi években már mérsékelt intenzitásúra csökkent migrációs folyamatba, mely a közép-kelet-európai országokat mint egységes bevándorló régiót jellemzi (Hárs 2010). A kialakult új migrációs rendszerben jelen voltak a rövid távú, határon átnyúló, ismétlődő mozgások, melyek eredeti célját a külföldiek tartózkodását szabályozó politika kijátszására álturizmus mögé rejtették (alkalmi munkavállalók, idénymunkások, csencselők), de hasonló technikát alkalmaztak a szomszéd országból hosszabb idejű tartózkodási, letelepedési, munkavállalási szándékkal érkező külföldiek is (Rédei 2006). 
A kilencvenes években a politikai, etnikai okokból eredő bevándorlási hullám csendesedett, az ezredfordulóra előtérbe került a gazdasági célú migráció. A migráció dinamikájában bekövetkezett változás nem hagyta érintetlenül a külföldiek számára munkát biztosító gazdasági ágazatok szerkezetét sem. A vendégmunkásokat foglalkoztató ágazatok közül egyaránt szerepük van a szolgáltató és termelő ágazatoknak, legkisebb vonzerővel a mezőgazdaság rendelkezett, és ez napjainkra sem változott: a mezőgazdaságban a külföldiek 1,2 százaléka dolgozik (Hárs 2010).

A kilencvenes évek elején az állam a helyi munkaerő-piaci helyzet kötelező vizsgálata után kiadott engedélyhez kötötte a külföldi állampolgárok foglalkoztatását. ${ }^{5}$ A rendeletekkel többször módosított szabályozás ${ }^{6}$ - Románia Európai Unióba lépése után - lehetővé tette a román állampolgárok számára 219 szakmában, valamint a mezőgazdasági idénymunkában az engedély automatikus kiadását („könnyített engedélyezés”). 2009. januártól Magyarország korlátozás nélkül megnyitotta munkaerőpiacát az EU-tagországok állampolgárai és hozzátartozóik előtt.7 További könnyítést jelentett, hogy a külföldi állampolgárságú munkások foglalkoztatását lehetővé tették az egyszerűsített foglalkoztatás keretében.

A kilencvenes évek közepén 18000 külföldi rendelkezett bevándorlási, letelepedési engedéllyel, minden harmadik településen élt külföldi állampolgár, de csak minden huszonötödik település polgármestere jelezte külföldi vendégmunkások jelenlétét. Számuk az adatközlések szerint nem haladta meg a négyezret (Dövényi 1996). A vendégmunkások száma folyamatosan emelkedett a kilencvenes években, majd az évezred fordulóján megtorpant, és Magyarország (2004), valamint Románia (2007) EU-hoz való csatlakozásával, a tagországok munkaerőpiacának könnyebb elérhetőségével egyre kevesebb román állampolgár vállalt munkát Magyarországon (1. táblázat).

A külföldi vendégmunkások számának apadása nem hagyta érintetlenül a mezőgazdaságot sem. A Nemzeti Foglalkoztatási Szolgálat jelentése szerint 2009-ben 4712 fő vállalt mezőgazdasági munkát, 2013-ra számuk kétharmaddal,

1. táblázat: Kiadott munkavállalási engedélyek és a foglalkoztató által bejelentett munkavállalók száma

Number of work permits and that of workers reported by the employers

\begin{tabular}{lrrrrrrrrrrr}
\hline \multirow{2}{*}{ Állampolgár } & 2004 & 2005 & 2006 & 2007 & 2008 & 2009 & 2010 & 2011 & 2012 & 2013 \\
\cline { 2 - 11 } & \multicolumn{10}{c}{ szám } \\
\hline Román & 42879 & 35547 & 33136 & 19006 & 15136 & 12566 & 6889 & 6368 & 4521 & 4176 \\
Ukrán & 10455 & 8854 & 8911 & 7770 & 7265 & 3534 & 4024 & 2604 & 2170 & 1131 \\
Összesen & 64695 & 53324 & 52505 & 37586 & 42457 & 28215 & 24535 & 22403 & 18891 & 18050 \\
\hline \multicolumn{10}{c}{ arány az összes munkavállaló százalékában } \\
\hline Román & 66,3 & 66,7 & 63,1 & 50,6 & 35,7 & 44,5 & 28,1 & 28,4 & 23,9 & 23,1 \\
Ukrán & 16,2 & 16,6 & 17,0 & 20,7 & 17,1 & 12,5 & 16,4 & 11,6 & 11,5 & 6,3 \\
\hline
\end{tabular}

Forrás: Külföldi állampolgárok magyarországi munkavállalásának fó sajátosságai (éves jelentések), Nemzeti Foglalkoztatási Szolgálat (NFSZ). 
2. táblázat: A szezonális munkavállalási engedéllyel rendelkezők száma Number of employees holding seasonal work permits

\begin{tabular}{|c|c|c|c|c|c|c|c|c|}
\hline \multirow[t]{2}{*}{ Állampolgár } & 2006 & 2007 & 2008 & 2009 & 2010 & 2011 & 2012 & 2013 \\
\hline & \multicolumn{8}{|c|}{ szám } \\
\hline Román & 1897 & 580 & 249 & & & & & \\
\hline Ukrán & 284 & 303 & 358 & 276 & 437 & 380 & 165 & 273 \\
\hline \multirow[t]{2}{*}{ Összesen } & 2216 & 907 & 651 & 366 & 447 & 380 & 170 & 280 \\
\hline & \multicolumn{8}{|c|}{ az összes arányában } \\
\hline Román & 85,6 & 63,9 & 38,2 & & & & & \\
\hline Ukrán & 12,8 & 33,4 & 55,0 & 75,4 & 97,8 & 100,0 & 97,1 & 97,5 \\
\hline
\end{tabular}

Forrás: Külföldi állampolgárok magyarországi munkavállalásának fó sajátosságai (éves jelentések), Nemzeti Foglalkoztatási Szolgálat (NFSZ).

1598 före csökkent. Hasonló folyamat ment végbe az idénymunkák piacán is, 2005-ben 2307 mezőgazdasági idénymunkára jogosító engedélyt adtak ki, 2009re számuk 80 százalékkal csökkent (2. táblázat).

Statisztikai adatok nem állnak rendelkezésre, de termelőkkel és munkaszervezőkkel készített interjúkból tudjuk, hogy a romániai mezőgazdasági idénymunkások számának apadása már az ezredfordulón elkezdődött, mely nagyobb lendületet 2003-tól vett. A folyamat erősödésének közvetlen kiváltója a román állampolgárok vízumkötelezettségének megszüntetése volt a legtöbb uniós országban, 2002-ben. 2009-től már nem rendelkezünk megbízható adattal a romániai idénymunkások számáról, azonban nagyon árulkodó a 2006 és 2008 közötti időszakban végbement változás, a munkások létszámának közel 90 százalékos csökkenése. A román állampolgárságú szezonális munkavállalási engedéllyel rendelkezők kétszer nagyobb arányban léptek ki a munkaerőpiacról, mint a munkavállalási engedélyes romániai munkavállalók. A zuhanásszerű csökkenésben közrejátszhatott a nagyobb mozgástérrel rendelkező munkavállalói csoport kedvezőbb társadalmi összetétele (az áttelepülő magyar etnikumú családok, a stabil munkahely) éppúgy, mint az idénymunkások számára magasabb jövedelemmel kecsegtető nyugati országok munkaerőpiacainak könnyebb elérhetősége.

A nagy bevándorlási hullám csendesedésével, a gazdasági célú migráció dominánssá válásával a magasabb iskolai végzettségűek rovására a migránsok összetétele is átalakult. 2007-ben az átlagos romániai vendégmunkás alacsonyan iskolázott férfi volt, aki a szakképesítést nem igénylő foglalkozásokban - elsősorban az építőiparban - helyezkedett el segéd- vagy betanított munkásként (Németh 2009). Az idénymunkások összetételében hasonló változások mentek végbe, mint a vendégmunkásokéban. A kilencvenes években a romániai szakmunkások és diplomások (Bertalan 1997; Fox 2005) is vállalták a gyümölcsszedést vagy a kertészeti munkákat, az ezredfordulóra azonban jelenlétük visszaszorult. Az évezred elejére a Romániából érkező, jelentős részben magyar idénymunkások kiléptek az idénymunka piacáról, a hiányzó munkaerőt pedig az ukrajnai munkások csökkenő száma nem pótolhatta (2. táblázat). 


\section{Az idénymunkások területi jellemzői}

A külföldi munkavállalók térbeli elhelyezkedését a kilencvenes évektől a települési lejtővel ellentétes irányú mozgás jellemzi. A migránsok legtöbbször városokban és nagyközségekben vállalnak munkát (Sik 1999), és állampolgárságuktól függetlenül a migrációs centrumnak számító Közép-Magyarország régióban koncentrálódnak (Kincses 2012). A romániai vendégmunkások 70 százaléka választ közép-magyarországi foglalkoztatót, általában a Szeged-Kecskemét-Cegléd-Budapest-tengely menti települések elérhető munkahelyei mellett döntenek (Németh, Csite, Jakobi 2009). Az ukrajnai vendégmunkások is szívesen dolgoznak Közép-Magyarország városaiban, a 2009-ben kiadott munkavállalási engedélyek több mint 80 százalékát Közép-Magyarország régióra állították ki, míg a két alföldi régió együttes részesedése nem haladta meg a 9 százalékot (Langerné Rédei, Karácsonyi 2011).

Az Ukrajnából érkezők számának apadását, a magyarországi munkavállalás visszaszorulását az alacsony iskolai végzettségűek esetében a munkavállalási engedélyhez kapcsolódó magas költségek, a kapcsolati háló gyengesége magyarázza, míg az iskolázottabbak számára, akik könnyebben kapcsolódnak be a migrációs hálózatokba és vállalják a költségeket is, a magyar munkaerőpiac már nem vonzó, ők a nyugat-európai országokat célozzák meg. Az általános okok mellett az idénymunkások számának visszaszorulásához hozzájárulhatott a határ menti térségek jelentőségének csökkenése is. A migránsokat, akárcsak a bevásárolni érkezőket képtelenek megtartani a határ menti térségek, s aki vállalja a vendégmunkával járó költségeket és kockázatokat, már nem elégszik meg a mezőgazdasági idénymunkával (Karácsonyi, Kincses 2010; Koltai, Sik 2012; Langerné Rédei, Karácsonyi 2011).

Az ukrajnai idénymunkások száma alacsony - a Nemzeti Foglalkoztatási Szolgálat éves jelentése szerint 273 fó - és munkavállalásukat a határ közelsége határozza meg. A 2013-ban kiadott 11102 szezonális engedély 96 százaléka Szabolcs-Szatmár-Bereg megye térségeire szólt. A Nagykállói és a Nyíregyházi kistérségeket csak egy-egy település (Újfehértó, illetve Nyíregyháza) képviseli, a legnagyobb foglalkoztatónak a Fehérgyarmati kistérség tizenhárom településének gazdálkodói bizonyultak, itt koncentrálódik a kiadott engedélyek 34 százaléka. Szabolcs-Szatmár-Bereg megye mellett csak Szentesen és a Mosonmagyaróvári kistérség két településén vállaltak munkát. Míg a munkavállalási engedélyre kötelezett ukrán állampolgárok területi jellemzőiről megbízható képet nyerhetünk, ez már nem mondható el a csak bejelentésköteles romániai munkásokról (1. ábra).

A román állampolgárok engedély nélkül vállalhatnak munkát, és kutatási tapasztalataink szerint a mezőgazdasági csúcsmunkák idején nagy számban dolgoznak olyan településeken is, melyek a Nemzeti Foglalkoztatási Szolgálat statisztikájában nem jelennek meg. 2013-ban romániai mezőgazdasági idénymunkás foglalkoztatására 2063 bejelentést regisztráltak a munkaügyi központok (egy munkavállaló többször is szerepelhet a statisztikában). A Romániából 
1. ábra: A bejelentett romániai munkások megoszlása kistérségek szerint, 2013

Distribution of registered Romanian workers by Hungarian micro-regions, 2013

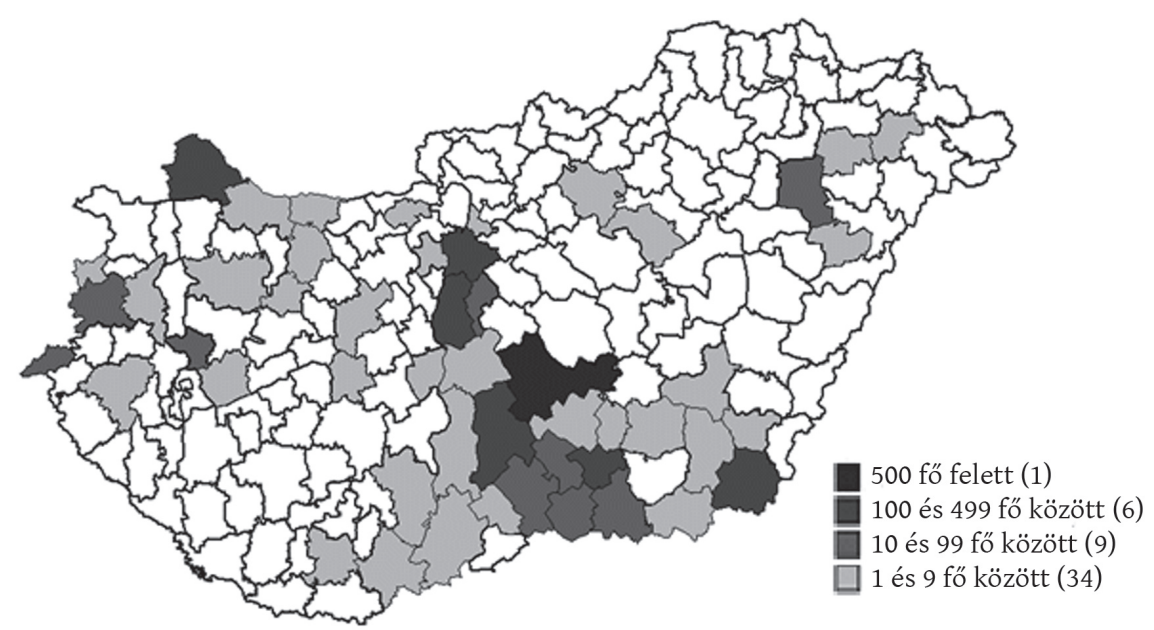

Forrás: Nemzeti Foglalkoztatási Szolgálat.

érkező munkaerőt a Dél-alföld régió gazdaságai kötötték le legnagyobb arányban, a bejelentett foglalkoztatás több mint 70 százalékát ebben a régióban biztosították. Régión belül Bács-Kiskun megye bizonyult a legnagyobb munkaerő-felvevőnek, kistérségeiben (Kecskeméti, Kiskőrösi, Kisteleki kistérségek) rögzítették a megyei központok az összes bejelentés 65,1 százalékát. A megye kiterjedt szőlö- és gyümölcsültetvényeinek munkaerö-szükséglete biztos keresetet nyújtott a kilencvenes évektől a romániai idénymunkásoknak, és számuk csökkenése ellenére valószínűsíthető, hogy a munkáltatók az elkövetkezendő években sem mondanak le idénymunkásaik munkájáról. Elhelyezkedésük másik jellegzetessége, hogy az Észak-alföld régió munkahelyei nem jelentenek számukra vonzerőt, jelezve a rendelkezésre álló hazai munkaerő térbeli elérhetőségének egyenetlenségét.

Az idénymunkások harmadik, és kétségkívül legkisebb csoportját a szerbiai munkavállalók képviselik. 2013-ban 365 engedélyt állítottak ki részükre, és két, határhoz közel fekvő település kertészetei foglalkoztatták őket.

Az idénymunkát vállaló külföldi munkások számában bekövetkezett apadás mértékét jelzi, hogy az egyszerüsített foglalkoztatás keretében a legnagyobb munkacsúcs (szőlő- és almaszüret) idején számuk közel 1000 fő volt, igaz, azt is figyelembe kell vennünk, hogy az idénymunkások „elsődleges területe” nem a szőlö-, hanem a csonthéjas ültetvények (Ehretné, Hamza, Rácz 2015). A mezőgazdaság nagy élőmunkaigénye mellett legálisan foglalkoztatott külföldi vendégmunkások számának folyamatos csökkenése és erős térbeli differenciálódása a mezőgazdasági idénymunkapiac átrendeződésére utal.

A kedvezőtlen foglalkoztatási helyzetű Szabolcs-Szatmár-Bereg megyében a külföldiek legális munkavégzése mindig nagyon alacsony szintủ volt, a foglalkoz- 
tatás a határ menti térségekben döntőrészt a feketegazdaságban szerveződött. Napjainkban az ország legnagyobb gyümölcstermelő megyéjében az idénymunka piacán a helyben élő munkaerő foglalkoztatása vált általánossá, ami nem zárja ki a külföldiek részvételét az alkalmi munkában, ám annak formája változott. A szatmári kistérségekben már csak a kisebb gyümölcsösökben vannak jelen továbbra is - többé-kevésbé a régi etnikai összetételben - a romániai munkavállalók. Romániai magyar vállalkozók a termény betakarításához a munkaerőt és a göngyöleget biztosítják, emellett az árut is eljuttatják a felvásárlótelepekre. A határ menti kistelepülések termelői a vegyes házasság előnyeit használják ki és a határon túlról érkező rokonok „,segítségére” számíthatnak.

A munkaerőhiányos vidékeken (pl. Dél-Pest megye) a romániai munkavállalók továbbra is a munkacsúcsok meghatározó szereplői maradtak, azonban egyre több munkaszervezéssel foglalkozó vállalkozó kínálja szolgáltatásait a külföldi vendégmunkások részleges vagy teljes kiváltására, illetve hiányának pótlására. A jelentős roma népességgel rendelkező, mindig is az ország legszegényebb térségei közé tartozó Közép-Tisza-vidék települései biztosítják az olcsó, naponta utaztatott munkáscsoportokat, többnyire romákat, de növekvő arányban a nem roma szegényeket is.

\section{A munkaszervezés és hálózatok}

A mezőgazdasági idénymunkapiac kialakulásához, részben újjászerveződéséhez viszonylag gyorsan létrejöttek a munkaerőpiac intézményei, így a foglalkoztatási részpiac feladatát ellátó „emberpiac” is. Az egymással nem versengő helyi „emberpiacok” az alkalmi munkát vállalók elosztó intézményeiként működtek a határ menti települések kocsmáiban, vasútállomásain vagy az aprófalvas térségek jól megközelíthető falvaiban is. A piacok napjainkra elvesztették jelentőségüket, szemben a kilencvenes évek elejétől fejlődő személyközi kapcsolatok hálózatával (Sik 2010).

A migrációs hálózatok fennmaradásához számos érdek füződik, többek közt a potenciális foglalkoztatóké, akik a hiányzó munkaerőt a vendégmunkások soraiból pótolják. A hálózat fenntartását, a munkaerő toborzását megbízott alvállalkozói kapcsolataikon keresztül biztosítják. Az alvállalkozói rendszer nemcsak a migráns kapcsolati hálók sajátja, hanem a pótlólagos munkaerő elérésének kitaposott útját jelenti, mely a mezőgazdasági idénymunkások térbeli mozgását, munkavállalását is irányította. Az illegális romániai munkavállalók a kilencvenes évek elejétől jelen voltak a lokális munkaerőpiacon, ,álturistákként” érkeztek és ismerősi kapcsolatokon keresztül jutottak munkához. Ők jelentették egy-egy kapcsolati háló kiindulópontját és rajtuk keresztül váltak elérhetővé a kisebb egyéni gazdaságok számára az idénymunkások. Egy-egy termelő kapcsolatai nyitották meg az utat a többi gazdaság számára is, hogy (idény)munkásokra tegyenek szert (Bertalan 1997). 
A kilencvenes években a migráns idénymunkások szervezésének egy másik rendszere is kiépült és működött az évtized végéig, melynek mozgatói a kiterjedt kertészeti kultúrával rendelkező nagyüzemek utódszervezetei vagy a nagyüzemekből kivált és önállósodott menedzsmentjei voltak. A gazdaságok megörökölték a hálózatokat (pl. nemzetközi építőtábor), a megváltozott viszonyok között csak a külföldi szervezéssel foglalkozó kapcsolattartó személyt kellett megtalálniuk, és érdekeltté tenni a szervezés folytatásában. A határon túli szervezést az egykori romániai ifjúsági szervezet csatornáit felhasználva végezték, a foglalkoztatáshoz szükséges jogi keretet, az adminisztrációt és a munkások gazdaságok közötti elosztását egy magyar szervezet (pl. diákszövetkezet) látta el. A szükséges munkaerő elérése versenyelőnyt jelentett a gazdaságok számára, amelyek élve a lehetőséggel, munkásaikkal bérmunkát is vállaltak ismerős termelők gyümölcsöseiben. Az ezredfordulóhoz közeledve az intézményesített szervezés és munkaerő-elosztás összeomlott, de addigra már a termelők kiépítették és megszilárdították saját hálózatukat, így csak a foglalkoztatás adminisztrációját (munkavállalás engedélyeztetése) kellett átvállalniuk.

A migráns munkások szervezését és területi eloszlását az utódszervezetek vezetőinek személyes kapcsolati hálója mozgatta és irányította, a kisebb gazdaságok vezetői azonban nem tartoztak ehhez a termelői körhöz. Ennek oka egyrészt az volt, hogy nem tartoztak a volt menedzsment belső kapcsolati rendszeréhez, sőt, a legerősebb egyéni gazdaságok vezetői sokszor politikai és gazdasági versenytársak voltak, másrészt nem rendelkeztek nagyobb létszámú csoport(ok) elhelyezésére alkalmas szállással, a szükséges infrastruktúrával. Így hozzáláttak saját hálózatuk megszervezéséhez, melynek kulcsfigurája a romániai munkaszervező volt. Az ezredfordulóra teljesedett ki a termelői hálózatok működése, melyben a gazdálkodó, a romániai munkaszervező és a munkások voltak a szereplök.

A termelői hálózatok a határ menti térségekre és megyékre terjedtek ki, a magyar nemzetiségü, fegyelmezett munkakultúrájú, iskolázottabb idénymunkások munkavállalását - hasonlóan a többi vendégmunkáshoz - a két ország közötti bér- és jövedelemkülönbségek, az anyagi gyarapodás, az életkörülményeik javítása motiválta (Bodó 2008, 2009). Megbízható források hiányában nehéz eldönteni, hogy a kilencvenes években megjelenő romániai munkások konkurenciát jelentettek-e a lokális vagy térségi piacon elérhető hazai munkaerő számára, kiszorították-e a helyi munkaerőt, vagy csak a gazdaságok számának emelkedésével jelentkező munkaerőhiányt csökkentették.

Függetlenül a gazdaság földrajzi fekvésétől és nagyságától, a hálózat kiterjedtségétől, az évezred elejére általánossá vált a magyar nemzetiségü, külföldi illetőségű idénymunkások számának drámai apadása. A vendégmunkások lemorzsolódása többszörösen is érzékenyen érintette a termelőket. Az olcsó munkaerő jelentős bevételnövekedést, versenyelőnyt biztosított az üzemek számára. A feldolgozóiparban zajló változások, az EU-csatlakozással megjelenő minőségi követelmények, valamint az idénymunkások számának csökkenése 
gyengítette a termelők piaci helyzetét. Ráadásul az évezred első éveiben fordultak termőre a kilencvenes évek végén telepített gyümölcsösök - csak Szabolcs-Szatmár-Bereg megyében több mint 15 ezer hektár -, melyek kézimunkaigényét is biztosítani kellett, miközben a rendelkezésre álló munkaerő száma nagymértékben csökkent.

Az ezredforduló óta a külföldi migránsok idényjellegű foglalkoztatására kiépített hálózatok közös vonása a sérülékenység, nemritkán az esetlegesség. A munkaszervezés térben követte a potenciális mobil munkaerőt, felértékelődtek azok a romániai megyék, települések, ahol magas a roma népesség aránya. A munkaerőt kereső termelők és szervezőik a határ menti Bihar megye mellett eljutottak Kolozs és Maros megyékbe is. Az üzemek munkaerő-szükségletét a nem roma vendégmunkások kiesése után jelentős részben a magyar és román nyelvü roma migránsok biztosítják. A szükséges létszámú munkás biztosítása kiszámíthatatlanná vált, csak kevés termelő tudott stabil hálózatot kialakítani. A hálózatok sérülékenységét fokozta, hogy a munkaerőhiánnyal küzdő üzemek vezetői a munkások átcsábításával és/vagy a vendégmunkások rokoni-ismerősi körére támaszkodva kísérelték meg hálózatuk bővítését. Ebben nem kis szerepet játszik, hogy a magyarországi termelők a külföldi munkaerő biztosításához nem építettek ki jogilag is elfogadott munkaerőt közvetítő intézményt (pl. ügynökség), és a munkavállaló, a foglalkoztató gazdasági viszonya továbbra is a személyközi kapcsolatokon és nem szerződésen alapul.

\section{Az idénymunkások csoportjai}

\section{Migráns idénymunkások}

A romániai cigány idénymunkások már a kilencvenes évek elején megjelentek a munkaerőpiacon, a kunsági borvidék gazdaságaiban (Bíró, Oláh 2002) vagy a dél-pesti térség falvaiban, de a munkaerőhiányos térségekben az elmúlt közel tíz év alatt váltak az idénymunkapiac fontos szereplőivé. A nagy ültetvények Romániából érkező munkaerőre rendezkedtek be, évek óta több mint száz munkást foglalkoztatnak a dömpingmunkák idején, a kisebb üzemek egy-egy családdal (klánnal) alakítottak ki kapcsolatot.

A munkaerőhiányos térségben a termelők szerint jobb minőségű munkát végző, de volumenben kis teljesítményü helyi napszámosok foglalkoztatását a romániai idénymunkások számához igazítják. A munkásszállássá átalakított, berendezett épületekben, tanyákon elszállásolt migránsok megítélése ambivalens. A termelők általános problémaként említik a magas fluktuációt, a munkások alacsony munkakultúráját, a szabályok be nem tartását, a megállapodások felrúgását. Ebben nem kis szerepet játszanak maguk a termelők is, egyrészt a 
munkások számára a nagyobb területű, több munkalehetőséget kínáló gazdaságok tagadhatatlanul nagyobb vonzerővel rendelkeznek, ugyanakkor jellemző a munkásokért folytatott verseny, a munkavállalók már említett, konfliktusokat is gerjesztő átcsábítása. Kivételnek számít az a termelő, aki elégedett az évente visszatérő munkások teljesítményével, munkakultúrájával, akik „végigdolgozzák a napot, a családfó fegyelmet tart, nem isznak, nem dohányoznak és rendben tartják a munkásszállást”. A munkások és a foglalkoztató kapcsolatának érzékeny pontja a munkabér. Évekkel korábban a külföldi idénymunkások a hazai napszámosoknál olcsóbban vállaltak munkát, azonban a munkaerőhiány, a munkások más térségekben szerzett munkavállalási tapasztalatai napjainkra ezt a különbséget megszüntették. Míg kezdetben „egy tál ételért is vállalták a munkát", most már előfordul, hogy választás elé állítják a termelőt, vagy magasabb bért fizet, hogy a minőségi követelményeknek megfelelő munka ne lassítsa a munkateljesítményt, vagy más gazdaságban próbálnak szerencsét.

A munkások arra törekednek, hogy nagyobb gazdaságokban tudjanak munkát vállalni, ahol a szezon nemcsak két-három hónapig tart, hanem van esély a négy-öt hónapos foglalkoztatásra, és a következő évi munkavállalásra is. A hosszabb idejű és ismétlődő foglalkoztatásra annál nagyobb az esély, minél jobban megközelíti valaki az ideális napszámostól elvárt munkát, azaz hajnalban kel, végigdolgozza a napot, este holtfáradtan bemegy a szállásra az ágyára, hogy pihenjen. Ha azt mondják neki, hogy meg kell rakni egy kamiont vagy meg kell csinálni még egy sávot a gyümölcsösben, felkel és szó nélkül megcsinálja.

\section{Áttelepült idénymunkások}

A vendégmunkások legmozgékonyabb, törekvő, megbízható munkát végző csoportja, élve a letelepedés és az egyszerüsített honosítás (Gödri 2013) lehetőségével, áttelepedett Magyarországra és felvette a magyar állampolgárságot. E csoport tagjai szüleikkel gyerekként vagy fiatal felnőttként már a kilencvenes évektől rendszeresen jártak vissza egy-egy településre, ahol kialakították kapcsolataikat a helyi gazdálkodókkal. A szülők, a testvérek, ha nem is azonos, de egymáshoz közeli településeken telepedtek le, jövedelmükből általában egy rosszabb állapotú ház, tanya megvásárlására futotta. A családos idénymunkások letelepedtek, egy-egy erősebb gazdaság biztosít számukra munkát és egzisztenciális hátteret, a termelővel kialakult kapcsolatuk sajátos egyvelege a klienspatrónus és a gazda-kommenciós cseléd viszonyának. Az utóbbira jellemzo,, hogy a gazda tanyáján laknak, lakbért nem, csak az áramot kell fizetni, ingyen kapnak tüzelőt, van, akinek munkaadója saját állományából egy malacot ad és a hízóvá neveléshez szükséges takarmányozást is biztosítja. A juttatásokért cserébe a gazdaság körüli mindennapi teendőket is ellátják (állatok etetése, kisebb munkák). A kliens-patrónus viszonyra hajaz a hivatalos ügyek intézésében nyújtott segítség, a téli hónapokra félrerakott pénz fogytával a munkás „kisegí- 
tése" előleggel, amit majd idényben ledolgozik, vagy a gazda születésnapi ünnepségén való részvétel, melynek íratlan szabálya az ajándék vásárlása.

Bár megélhetésük fő bázisa a gazdaság, munkaszerződésük nincs, az idény elindulásával egyszerüsített foglalkoztatottként regisztrálják őket. Nincs megegyezés a fizetési határidőkről sem, általában hetente-kéthetente kapják meg bérüket, „vagy amikor szükségük van rá”. Ha a gazdaságban nincs munka, a gazda elengedi őket dolgozni, hogy kereshessenek, gyarapodhassanak, vagy maga küldi át a munkásokat, hogy kisegítse gazdatársát. A család nélküliek idényben a gazdaságban dolgoznak, télen megélhetésüket az erdészetnél vagy a vízügynél közmunkásként teremtik meg.

Az önálló ház vásárlása - legyen az egy kis tanya vagy egy elöregedő falu belterületén álló családi ház - vízválasztónak bizonyul, mely nemcsak a jobb anyagi helyzetet jelzi, hanem a felemelkedéshez szükséges mozgástér fokozatos bővítését is lehetővé teszi. Az anyagi gyarapodás legbiztosabb útja a napszámosként megtanult termesztési eljárások hasznosítása, melyhez viszonylag kis anyagi ráfordítással lehet hozzákezdeni és fokozatosan bővíteni (pl. epertermesztés), belterületi telek vagy a tanya melletti föld bérlésével.

Az áttelepült idénymunkások és a gazdaság közötti kapcsolat fontos eleme, hogy az áttelepültek vették át a munkaszervezők feladatát, melyet hatékonyabban és olcsóbban látnak el, mint a termelőhöz nem vagy csak laza szálakkal kötődő, kizárólag létszámban gondolkodó szervezők. A gazdaság az áttelepültek kapcsolati hálóin keresztül biztosítja a szükséges létszámú és megbízható munkást, így a szezonális munka is tervezhető lesz.

\section{Összegzés}

Az agrárium strukturális átalakulása, az üzemek számának és munkaerőigényének ugrásszerű növekedése az idénymunka piacának kialakulásához, új munkavállalói csoportok megjelenéséhez és a hagyományos munkaszervezési formák újraéledéséhez, felerősödéséhez vezetett. Az olcsó bérezésű, a foglalkoztató szükségleteihez rugalmasan alkalmazkodó munkavállalók között a külföldi idénymunkások megjelenése a kapcsolati hálók, a munkaszervezési formák térbeli, országhatárt átlépő kiterjesztéséhez, gazdagodásához, a rendelkezésre álló munkások számának emelkedéséhez vezetett. A migránsok belépése a munkapiacra nem kis arányban a feketegazdaságban szerveződött, napjainkban az idénymunka piaca térben és időben is töredezett, intézményei a "láthatatlan" személyközi kapcsolatokra épülnek, és minden változás ellenére a fekete vagy a szürkegazdasághoz is kapcsolódnak.

A külföldi idénymunkások számának csökkenésével, etnikai és társadalmi összetételének változásával a migránsokat mozgató termelői hálózatok részben meggyengültek, részben differenciálódtak, de vannak olyan térségek is, 
ahol teljesen eltűntek. A magyar termelők, uniós társaikhoz hasonlóan, képtelenek voltak megtartani a megbízható migráns munkaerőt. Ebben a folyamatban a munkavállalók oldalán az uniós országok munkaerőpiacain elérhető magasabb jövedelem játszott szerepet. A termelők oldalán az vezetett a változásokhoz, hogy könnyen elérhető volt számukra az olcsó munkaerő, a gazdálkodás jövedelmezőségét a bérek alacsony szinten tartásával biztosították, továbbá, hogy a munkásokért egymással is versengő gazdaságok kultúrájából hiányzott a szándék a munkaerő szervezését ellátó közös intézmény létrehozására, működtetésére.

Vízválasztónak az évezred első évei bizonyultak, nemcsak azért, mert a migránsok létszámbeli fogyatkozása és összetételének változása ekkor kezdődött, hanem azért is, mert erre az időre a gazdaságok egy része kialakította és megszilárdította azt a kapcsolathálót, mely napjainkban is biztosítja számukra a szükséges létszámú migráns munkaerőt. A külföldi idénymunkások merítési bázisa folyamatosan zsugorodik, a legtöbb gazdaság számára a munkacsúcsok munkaerőigényének biztosítása növekvő nehézséget és gazdasági kockázatot jelent. A munkaerőhiányos térségekben ugyanakkor még mindig a migráns munkások száma határozza meg a hazai napszámoslétszámot.

A migráns mezőgazdasági idénymunkások heterogén csoportjai között az elmúlt másfél évtizedben végbement a foglalkoztató számára értékes munkavállalói kör kiválasztása. Azok a termelők rendelkeznek stabil kapcsolathálóval, akik letelepedett idénymunkásokat foglalkoztatnak, vagy évek alatt jó kapcsolatot alakítottak ki Romániában élő, rendszeresen visszatérő nagycsaláddal/családokkal, és változó munkaerő-szükségletüket munkásaik hálózatain keresztül biztosíthatják. A munkások gazdasághoz kötésének sikerességében szerepet játszott az etnikai migráció támogatása, különösen az egyszerűsített honosítás bevezetése, a kettős állampolgárság lehetősége. A foglalkoztató gazdálkodó, valamint a romániai magyar és cigány áttelepült bérmunkások gazdasági kapcsolata nem ritkán magán viseli a kliens-patrónus és/vagy a gazda-kommenciós cseléd viszony jegyeit is. Kétségtelen, hogy előnyben vannak az áttelepült munkaerőt foglalkoztató üzemek az évente visszatérő idénymunkást alkalmazó társaikkal szemben, mert a munkásokkal kialakított kapcsolatuk biztosítja számukra az idénymunka tervezhetőségét. Ugyanakkor bármennyire is látványos a külföldi munkások számának csökkenése, a két ország közötti bér- és jövedelemkülönbségek miatt a munkaerőhiányos térségekben valószínűleg megőrzik szerepüket.

\section{Jegyzetek}

1 A tanulmány az NK 100675 számú, Földből élők c. OTKA-projekt támogatásával jött létre. A szerző ezúton fejezi ki köszönetét a kapott támogatásáért. 
2 A tanulmány megírásához 12 termelővel és 8 idénymunkással készült interjút használtunk fel.

3 Az időszaki alkalmazott statisztikai fogalom. Az agrárösszeírások meghatározása szerint az időszaki alkalmazottak az állandó alkalmazottaktól eltérően nem végeznek heti rendszerességgel, egy éven keresztül munkát a gazdaságban. Munkavégzésük szezonális jellegü (betakarítás, metszés stb.). (Útmutató a kérdőív kitöltéséhez, valamint Fogalomtár, GSZÖ 2013. KSH, Budapest)

4 Az alkalmi munkavállalói könyvvel történő foglalkoztatásról és az ahhoz kapcsolódó közterhek egyszerüsített befizetéséről szóló 1997. évi LXXIV., többször módosított törvény hatályát 2000ben terjesztették ki a verseny- és a közszférára. 2002-ben felére csökkentették a közteher értékét, és további 50 százalékos kedvezményt kaptak azok a munkaadók, akik regisztrált munkanélkülieket foglalkoztattak. Három évvel később már a ledolgozható éves munkanapkeretet 120 napról 200 napra emelték. 2010-ben az alkalmi munkavállalói könyves foglalkoztatást az egyszerüsített foglalkoztatás váltotta fel, melyet a 2010. évi LXXV. törvény az egyszerűsített foglalkoztatásról szabályoz. Jelentősen csökkentették a foglalkoztatók járulékterheit, egy mezőgazdasági idénymunkás foglalkoztatásához naponta 500 forint közterhet kell fizetni. A mezőgazdasági idénymunka tartamát 120 napban maximalizálták, nem kötelező a szerződéskötés, csak ha a munkavállaló kéri. A jogszabály lehetővé teszi külföldi állampolgárok foglalkoztatását is.

5 Az 1991. évi IV. törvény a foglalkoztatás elősegítéséről és a munkanélküliek ellátásáról.

6 A 7/1991. (X. 17.) MüM rendelet a külföldiek magyarországi munkavállalásának engedélyezéséről, 8/1999. (XI. 10.), SzCsM rendelet a külföldiek magyarországi foglalkoztatásának engedélyezéséről, 354/2006. (XII. 23.) Korm. rendelet a Bolgár Köztársaságnak és Romániának az Európai Unióhoz történő csatlakozását követően a Magyar Köztársaság által alkalmazandó, a munkavállalók szabad áramlására vonatkozó átmeneti szabályokról.

7 A 355/2007. (XII. 23.) Korm. rendelet a Magyar Köztársaság által a szabad mozgás és tartózkodás jogával rendelkező személyek tekintetében alkalmazott, a munkaerő szabad áramlásával összefüggő átmeneti szabályokról.

\section{Irodalom}

Andrzejewska, J., Rye, J. F. (2012): Lost in transnational space? Migrant farm workers in rural districts. Mobilities, 2., 247-268. http://doi.org/6gs

Bertalan B. (1997): Feketemunka importból, avagy a hétköznapi diplomácia eredete? In: Sik E. (szerk.): Migráció és politika. MTA PTI, Budapest, 121-134.

Bíró A. Z., Oláh S. (2002): Helykeresők. Roma népesség székelyföldi településeken. In: Bodó J. (szerk.): Helykeresők? Roma lakosság a Székelyföldön. KAM, Regionális és Antropológiai Kutatások Központja, Csíkszereda, 11-48.

Bíró Sz., Székely E. (2012): A mezőgazdasági foglalkoztatás bővitésének lehetöségei vidéki térségeinkben. AKI, Budapest

Bodó J. (2009): A vendégmunka típusú migráció magatartásmintái a székelyföldi térségben 1-2. Fórum Társadalomtudományi Szemle, 1., 117-135 és 2., 41-58.

Bodó J. (2008): Diskurzusok és életutak a migráció tükrében. Scientia Humana, Budapest

Dövényi Z. (1996): Adalékok a Magyarországon élő idegenek területi megoszlásához. In: Sik E., Tóth J. (szerk.): Migráció és politika. MTA PTI, Budapest, 97-105.

Ehretné Berczi I., Hamza E., Rácz K. (2015): A munkaerő-felhasználás jellegzetességei a zöldség- és gyümölcságazatban. Zöldség-Gyümölcs Piac és Technológia, 2.

Fox, J. E. (2005): Vándorló nemzet(i) identitások. Erdélyi vendégmunkások Magyarországon. In: Feischmidt M. (szerk.): Erdély-(de)konstrukciók. Tabula könyvek, Budapest, Pécs, 103-122.

Frey M. (2010): A foglalkoztatási törvényben rögzített és az ÁFSZ által múködtetett, továbbá az ezeken kívül szabályozott és bonyolitott aktív munkaerőpiaci eszközök értékelése a 2004-2009. közötti időszakban. Tanulmány az „Aktív munkaerőpiaci politikák komplex értékelése” c. kutatáshoz. Budapest. www.afsz.hu/resource.aspx?ResourceID=tamop_131...3 (Letöltés: 2014. január 10.) 
FruitVeb (2012): Magyar zöldség-gyümölcs ágazati stratégia. Budapest. http://www.fruitveb.hu/ kiadvany/magyar_zoldseg-gyumolcs_agazati_strategia_2012.pdf (Letöltés: 2013. szeptember 4.)

Gödri I (2013): Migráció nemzeti/nyelvi határokon belül. Bevándorlók és új állampolgárok a szomszédos országokból - változó trendek. Magyar Tudomány, 3., 263-275.

Hárs Á. (2010): Migráció és munkaerőpiac Magyarországon. In: Hárs Á., Tóth J. (szerk.): Változó migráció - változó környezet. KTI, Budapest, 15-56.

Jentsch, B. (2007): Migrant integration in rural and urban areas of new settlement countries: Thematic introduction. International Journal on Multicultural Societies, 1., 1-12.

Karácsonyi D., Kincses Á. (2010): Ukrán állampolgárok Magyarországon: nemzeti összetartozás és gazdasági kényszer. Területi Statisztika, 3., 334-349.

Kasimis, C. (2009): From enthusiasm to perplexity and scepticism: International migrants in the rural regions of Greece and Southern Europe. In: Simard, J. (eds.): International migration and rural areas: Cross national comperative perspectives. Ashgate, London, 75-98.

Katona I. (1961): Munkaszervezeti formák és ideiglenes életközösségek idénymunkákon a kapitalizmus korában. Agrártörténeti Szemle, 3-4., 534-562.

Kincses Á. (2012): A Kárpát-medence ezredforduló utáni migrációs hálózatának vizsgálata. KSH, Budapest

Koltai J., Sik E. (2012): Határokon átnyúló munkaerő-piaci és jövedelemszerző mozgások a „végeken”. In: Kolosi T., Tóth I. (szerk.): Társadalmi Riport, TÁRKI, Budapest, 209-226.

Koós B., Kovács K. (2012): A mezögazdasági foglalkoztatás jellemzői - Trendek és szabályozás. Kézirat, Budapest

KSH (2014): Magyarország mezögazdasága, 2013. Gazdaságszerkezeti összeírás - elözetes adatok. http://www.ksh.hu/docs/hun/xftp/idoszaki/gszo/gszo elozetes 2013.pdf (Letöltés: 2014. március 8.)

Langerné Rédei M., Karácsonyi D. (2011): Ukrajna migrációs jellemzői. In: Kincses Á. (szerk.): Ukrán állampolgárok Magyarországon. Európai Integrációs Alap, Budapest

Loughrey, J., Donnellan, T., Hanrahan, K., Henessy, T. (2013): Agricultural labour markets in the EU and candidate countries. In: Swinnen, J., Knops, L. (eds.): Land, labour and capital markets in European agriculture. Diversity under a common policy. Centre for European Policy Studies, Brussels, 24-38.

Mannon, S. E., Petrzelka, P., Glass, C. M., Radel, C. (2012): Keeping them in their place. Migrant women workers in Spain's strawberry industry. International Journal of Sociology of Agriculture and Food, 1., 83-101.

Nelson, P. B., Nelson, L.,.Trautman, L (2014): Linked migration and labor market flexibility in the rural amenity destinations in United States. Journal of Rural Studies, 36., 121-136. http://doi.org/6gt

Németh N. (2009): Kutatási jelentés a román állampolgárságú munkavállalók magyarországi jelenlétének vizsgálatáról. OFA Zárótanulmány. Budapest. http://www.ofa.hu/hu/munkaugyi+kutatasok/munkaugyi+kutatasok+2.htm (Letöltés: 2013. április 8.)

Németh N., Csite A., Jakobi Á. (2009): Román állampolgárságú munkavállalók Magyarországon. Területi Statisztika, 6., 615-627.

Preibisch, K. (2012): Migrant workers and changing workplace regimes in contemporry agricultural production in Canada. International Journal of Sociology of Agriculture and Food, 1., 62-82.

Rédei M.(2006): A nemzetközi migráció főbb folyamatai. Földrajzi Közlemények, 1-2., 29-38.

Sárközi Z. (1972): A summások. In: Szabó I. (szerk.): A parasztság Magyarországon a kapitalizmus korában I-II. Akadémiai Kiadó, Budapest, 321-381.

Semjén A., Tóth I., Fazekas M. (2008): Alkalmi munkavállalói könyves foglalkoztatás munkaadói és munkavállalói interjúk tükrében. MTA KTI, Budapest (Műhelytanulmányok; 2008/10.)

Sik E. (1999): Külföldiek Magyarországon és a velük kapcsolatos nézetek a helyi önkormányzatokban. TÁRKI, Budapest (Társadalompolitikai Tanulmányok; 11.)

Sik E. (2010): Emberpiac a Moszkva téren - szűkülő változatlanság. In: Czakó Á., Giczi J, Sik E. (szerk.): Piachely, KGST-piac, emberpiac. ELTE TáTK, Budapest, 343-374.

Soltész B. (2010): A gyümölcsszedés vége? Bolgár és román bevándorlók Spanyolországban. Délkelet Európa - South-East Europe, International Relations Quarterly, 2. http://www.southeasteurope.org/pdf/02/DKE_02_M_EU_SB.pdf (Letöltés: 2014. december 13.) 